\section{Food scientist in GMO row defends 'premature' warning}

[LONDON] The UK researcher at the centre of last month's storm over genetically modified foods says he has few regrets about publicly discussing unpublished research which, he claims, indicate that rats fed genetically modified potatoes suffered ill health.

Giving evidence to the House of Commons Select Committee on Science and Technology on Monday (8 March), Arpad Pusztai said he was concerned that genetically modified foods were being introduced

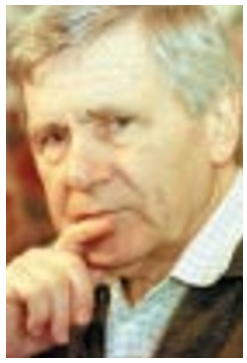

without adequate safety tests. Pusztai was formerly a senior researcher at the Rowett Research Institute in Aberdeen.

He told the committee that preliminary results from his experiments were causing him Pusztai: success in concern, and that he had stimulating debate. to take action. "What I have achieved is that we are all sitting here and talking about it."

Pusztai's call for tougher regulation of genetically modified products was backed by his former boss, Philip James, director of the institute, in evidence to the committee.

But the two men offered very different versions of the events of last August, when Pusztai's interview in a television documentary led directly to the recent panic over genetically modified foods.

Pusztai said on television that he had discovered that rats fed with potatoes modified to produce an insecticidal lectin called GNA suffered damaged immune systems and stunted growth. He said James spoke to his wife by telephone after the broadcast "to congratulate me on how well I handled the interview".

But the following day, Pusztai discovered that the Rowett institute had issued a press release claiming that he had inadvertently revealed the results of feeding studies with a different lectin, Con A, which is not used in food as its toxicity is well known.

Although Pusztai denies mixing his data, he says he was suspended and his data confiscated, and claims that staff were warned not to talk to him. James told the committee that Pusztai had not only seen the press release, but had rewritten part of it. "Pusztai had presented information that turned out to be untrue. There was confusion in his group, and his collaborators were outraged," said James.

An audit committee subsequently set up by Rowett said Pusztai's data on the effects of feeding rats with GNA modified potatoes did not support his claims.

Ehsan Masood

\title{
US State Department gets cold feet about cold fusion
}

[WASHINGTON] A meeting that was to have been held at the US State Department next month to highlight research on unconventional energy sources seems likely to be scaled down or cancelled because of doubts about the credibility of the research.

The First International Conference on Free Energy was to have taken place on 29 and 30 April at the State Department auditorium. The conference is sponsored by the Integrity Research Institute (IRI), a Washington-based group that promotes exotic energy concepts ranging from 'magnet power' to 'assisted nuclear reactions' — one description of cold fusion.

The department agreed more than a year ago to host the meeting as part of a programme oflunchtime talks meant to encourage dissenting views on foreign policy issues. IRI president Thomas Valone says this would be an appropriate venue because many of the 'free energy' concepts to be discussed would have a bearing on US compliance with the Kyoto climate-change treaty.

But the meeting has grown to a two-day conference, with more than a dozen speakers, and hundreds of people attending.

Meanwhile, responsibility for coordinating the Open Forums programme has changed hands twice at the State Department. According to Valone, the most recent individual to take on the job, Cora Foley of the department's Bureau of Intelligence and Research, questioned whether the department should support the conference shortly after assuming her post a few weeks ago.

Sources say Foley and other department officials have received e-mails and calls from mainstream scientists asking why the department is lending its name to a meeting they argue has little scientific merit.
After a meeting between Foley, Valone and others on Monday (8 March), the department remained undecided as to whether it will cancel or curtail its involvement in the conference. One source said the organizers were considering moving it to a hotel.

Valone, who is also a patent examiner with the US Patent and Trademark Office, found himself in hot water with his own agency last year when he sent out an Internet notice to "all able-bodied infinite energy technologists", inviting them to apply for examiner jobs at the agency and thereby "infiltrate" the office to encourage openness to unconventional ideas. Valone says he was chastised by the patent office, and admits he made a mistake in sending out the notice.

Robert Park of the American Physical Society, who often ridicules cold fusion and similar concepts in a weekly electronic newsletter on science policy, says he finds nothing wrong with a conference on free energy. "The problem is giving some sort of State Department imprimatur to it that makes it look like the federal government is taking this seriously," he says. "That's what these people are lusting for."

In fact, says Valone, one Australian researcher who planned to attend has used the State Department's involvement to try to enlist the participation of his government. Valone had hoped the department's endorsement "might have some effect worldwide".

The Department of Energy refused to act as a co-sponsor. One energy department researcher who still planned to attend, David Goodwin of the Office of High Energy and Nuclear Physics, says the agency felt "some apprehension about the cold fusion speakers", and agrees "it would be awkward for us" to sponsor the meeting.

Tony Reic hhardt

\section{f $150 \mathrm{~m}$ tax break for research in UK budget}

[LONDON] The British government has fulfilled earlier promises to provide tax relief for small high-technology companies. The move was announced in the government's budget on Tuesday (9 March).

Gordon Brown, the Chancellor of the Exchequer, Britain's finance minister, said that that the budget was intended to help turn Britain "into a modern knowledgebased economy", in particular by "championing the needs of small industry".

A tax credit worth a total of $\mathfrak{E} 150$ million will be available for small high-technology companies, allowing them, according to Brown, to "underwrite 30 per cent of their total research and development costs".
A sum of $\mathfrak{E 3 2 5}$ million is being set aside to allow small and medium size companies to set off capital investments against tax. And a $\mathfrak{E} 1.7$ billion 'computers for all' initiative is being launched to promote the use of information technology.

Brown announced that an additional $\mathfrak{E} 100$ million would be allocated to the science base to improve university laboratories and equipment, and that the funds allocated to the government's University Challenge scheme will be increased by 30 per cent.

He also announced measures to reduce Britain's greenhouse gas emissions by three million tonnes. 